\title{
THE YOUNGER CHRONIC SICK: HOW MANY BEDS?
}

\author{
B. T. WILLIAMS AND A. LAMBOURNE \\ Department of Community Medicine, University of Sheffield
}

The Chronically Sick and Disabled Persons Act (1970) is an expression of the increasing attention being paid to the needs of the handicapped in our society. The most severely physically handicapped represent only a small proportion of the total who are physically disabled (Harris, 1971) but their degree of dependency often makes it necessary to care for them in institutions, either in the form of residential homes or in special units in hospitals. For those who plan these hospital units, advice is available on the size, location, staffing, and equipment (Ministry of Health, 1968). No firm guidance can be found, however, on the question of how many places per unit of population to provide. In this paper we review the findings of the small number of surveys that have been conducted in recent years of the need for, and provision of, hospital places for the younger chronic sick; we predict the likely consequences of meeting this need with various levels of provision and we discuss the relative merits of a number of different admission policies for holiday relief cases.

\section{The Level of Need-VARiations Between Surveys}

The findings of recent surveys of the younger chronic sick in this country (Rankine and Weir, 1967; MacLennan, 1972; Nottingham University HMC and Nottingham and District HMC, 1971; Pearson et al., 1971; Ministry of Health, 1968) are difficult to compare due to variations in criteria.

The first variation occurred in the definition of 'younger chronic sick'. The long-term nature of the illness suffered is always stressed. In one survey, however, the definition was framed in terms of the specific duration of the disability (Pearson et al., 1971) while in a number of other surveys the cases in hospital were identified in terms of the predicted duration of further stay, e.g., indefinitely or until death (Ministry of Health 1968), or at least one year (MacLennan, 1972). It is not always clear whether patients in hospitals for short periods of relief have been included.

The age limits of the population studied varied from survey to survey (Table I).
TABLE I

VARIATIONS IN AGE LIMITS IN SURVEYS OF THE YOUNGER CHRONIC SICK

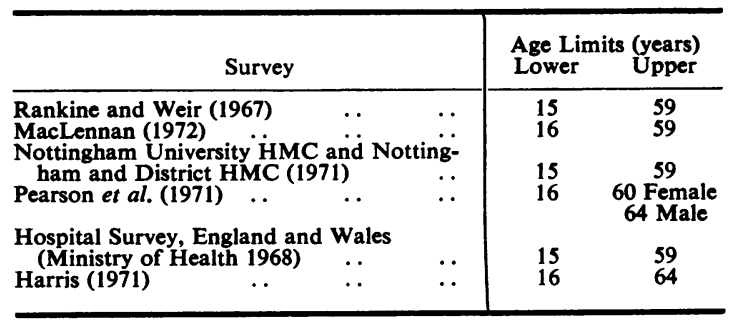

The variation of the upper age limit is important as the prevalence of permanent disability is higher in the 55-64 years age group than in any of the lower 10-year age groups (Harris, 1971).

One study dealt only with the handicapped in the community (Harris, 1971); another covered only the younger chronic sick in hospital (Ministry of Health, 1968); the remainder surveyed both the hospital and the community.

Some investigators have attempted to measure the unmet need for hospital care of the younger chronic sick existing in the community (Rankine and Weir, 1967; Nottingham University HMC and Nottingham and District HMC, 1971; Pearson et al., 1971; MacLennan, 1972). In only one of these studies, however, has the population surveyed been randomly selected (Pearson et al., 1971). The other community population samples have been drawn from lists of general practitioners selected for their willingness to co-operate. The levels of need uncovered in these practices were not necessarily representative of the need in other practices, therefore.

The assessors in these surveys were recruited from various professional backgrounds. They included consultant geriatricians (Rankine and Weir, 1967), a junior hospital doctor (MacLennan, 1972), a health visitor (Rankine and Weir, 1967), and medical social workers (Pearson et al., 1971). Some were employed 
specifically for the surveys, and others presented their findings from a day-to-day knowledge of their clientele.

The criteria of need for hospital care were not usually specified. Such criteria may be difficult to formulate. Judgements may vary between investigators as to the adequacy of the support possible for the younger chronic sick in the community. These levels of support may, in fact, vary from place to place. In only one study reporting unmet need of hospital care were the judgements of the investigators standardized (Pearson et al., 1971). Most of the survey reports, however, by careful case descriptions in terms of incontinence, immobility, and amount of attendance required by the patient, assist recognition of the type of case the investigators considered to be in need of hospital care.

In spite of these numerous sources of variation, the estimated levels of need for hospital care in the various areas fall within a fairly narrow range (Table II), with a mean level of 16 hospital places per 100,000 population. The level of need measured in each area, however, is subject to three further modifying factors.

First, some of the patients currently occupying hospital beds might have been accommodated more appropriately outside hospital. MacLennan (1972) estimated that in his own area 2 beds per 100,000 population were thus occupied.

Secondly, other institutions, such as Cheshire Homes, may have been accommodating residents whose degree of handicap better fitted them for care in hospital. The extent to which this applies is not known, though such evidence as exists suggests that disabled persons housed in residential homes are younger, less severely handicapped, and require less assistance than those in hospitals (Miller and Gwynne, 1972).

\section{TABLE II}

NUMBERS OF BEDS PER 100,000 POPULATION REQUIRED FOR YOUNGER CHRONIC SICK

\begin{tabular}{|c|c|c|c|c|}
\hline \multirow[b]{2}{*}{ Area } & & \multicolumn{3}{|c|}{ Beds per 100,000 for Persons: } \\
\hline & & $\underset{\substack{\text { In } \\
\text { now }}}{\text { Intal }}$ & $\begin{array}{c}\text { Needing } \\
\text { Hospital } \\
\text { now }\end{array}$ & Total \\
\hline $\begin{array}{l}\text { Fifo }(1966)^{1} \\
\text { Edinburgh }(1968-69)^{2} \\
\text { Exeter }(1968-69)^{2} \\
\text { Glasgow }(1970-71)^{3} \ldots \\
\text { Nottingham }(1971)^{4}\end{array}$ & $\begin{array}{l}\cdots \\
\cdots \\
\cdots \\
\cdots\end{array}$ & $\begin{array}{r}12 \cdot 0 \\
6 \cdot 2 \\
7 \cdot 0 \\
15 \cdot 4 \\
7 \cdot 1\end{array}$ & $\begin{array}{l}-* \\
9 \cdot 1 \\
9 \cdot 7 \\
3 \cdot 0 \\
6 \cdot 3\end{array}$ & $\begin{array}{l}15 \cdot 3 \\
15 \cdot 7 \\
18 \cdot 4 \\
13 \cdot 4\end{array}$ \\
\hline
\end{tabular}

- Not stated

1 Rankine and Weir (1967)

2 Pearson et al. (1971)

3 MacLennan (1972)

Nottingham University HMC and Nottingham and District HMC (1971)
Thirdly, the level of 'need' reported in each survey is that existing at one point in time and thus may not be an accurate estimate of the average level of need in that area. However, the consistency between the various survey estimates suggests that this is not too serious a source of error.

The level of need for hospital places for the younger chronic sick over the country as a whole can be derived theoretically from the results of two investigations conducted in 1967-68.

In April 1967, a census was taken of the number of younger chronic sick patients aged 15 to 59 in non-psychiatric hospitals in England and Wales (Ministry of Health, 1968). There were 4,223 such patients, of whom 224 were being accommodated to give temporary relief to those looking after them at home. The estimated population of all ages in England and Wales in 1967 was 48.5 million (Registrar General's Statistical Review). Thus 8.7 beds per 100,000 population of all ages were occupied by the younger chronic sick. In 1968, the Government Social Survey conducted a sample study of the handicapped in Great Britain (Harris, 1971). It was estimated that in a population of 32.9 million people aged 16 to 64 , there were 42,000 who were handicapped to a very severe degree. The report describes the criteria for classification which included the need for help with a commode, chamber? or bed pan practically every night, plus other handicaps such as having to be fed, to be dressed, etc. Of these $42,000,4,100$ were in the two most severe of the three categories of serious handicap. If we assume that these 4,100 people out of the population of 48.7 million would have benefited from hospital care, each 100,000 unit of population would require an extra 8.5 beds to house them. Together with the 8.7 beds already occupied by the younger chronic sick (assuming all were appropriately housed) the total need would be for $17 \cdot 2$ beds per 100,000 population; or if it is assumed that 2 of these beds were inappropriately occupied, 15.2 beds per 100,000 . The estimated figure of $17 \cdot 2$ beds per 100,000 is close to the average level of need derived from the field surveys $(16 \cdot 0)$.

We now discuss the adequacy of providing hospital beds at this average level, and at other levels for meeting the demand as it actually arises.

Simulation of a Younger Chronic Sick Unit

Using estimates of the 'hospital need' from these surveys, a simulation study was set up in order to estimate the optimal number of beds for the younger chronic sick. The only other simulation studies in recent years (Newell, 1954; Pike, Proctor and 
Wyllie, 1963; Young, 1965; Morris and Handyside, 1971) have dealt with the provision of beds for the acutely ill rather than the chronic sick.

\section{MeTHOD}

In order to cater for the needs of a population of 100,000 , a young chronic sick unit containing $N$ beds was simulated and its behaviour over a long period of time was studied.

For each patient an arrival time was generated, and this was compared with the first time at which a bed became empty. If arrival occurred after a bed had become empty, then the patient had no waiting time but the bed was standing idle for a period. If arrival occurred before a bed became empty, the patient had to wait but the bed was fully occupied. For the unlikely event of a patient arriving just as a bed became available, the patient had no waiting time and the bed was never empty. Depending on which of these three situations arose, both the patient's waiting time and the bed's idle time were calculated.

The duration of stay of the patient was then generated. When added to the date of occupation, this gave the date at which the patient vacated his bed and left it empty for another patient to occupy. The arrival time of the next patient was then generated and the process was repeated.

When enough patients had been simulated to provide reasonable estimates of the required information (such as the proportion of cases kept waiting, their mean waiting time, percentage bed occupancy) the process was terminated. How well the simulation fitted the real-life situation was tested by comparing known facts (such as the mean arrival rate, the mean and standard deviation of the duration of stay) with those obtained from the simulation.

In order to use this method certain assumptions were made about the rates of arrival and discharge of the patients.

These assumptions were:

(1) New CASES These, being relatively rare events occurring at random, were assumed to follow the Poisson distribution. Thus the probability that $n$ new cases would present during a time interval of length $t$ was given by

$$
\mathrm{P}(n)=e^{-a t} \frac{(a t)^{n}}{n !}
$$

where $a$ is the mean rate of admission per unit time $e$ is the exponential constant $(=2 \cdot 71828 \ldots)$ and $n !=n(n-1)(n-2)(n-3)$. . 4. 3. 2. 1.
Both Newell (1954) and Young (1965) found that this distribution was a good representation of the actual numbers of new cases presenting.

(2) Duration of Stay Several suggestions have been made about the distribution of the length of time that a patient will occupy a bed, once admitted. These duration of stay distributions include the negative exponential (Bailey, 1956), the lognormal (Balintfy, 1960), and the gamma (Young, 1965) distributions. As no other information was available, the negative exponential was chosen, by which the probability that a patient stays for $t$ years was given by

$$
\mathrm{P}(t)=\frac{e^{-\frac{t}{b}}}{b} \quad t \geqslant 0
$$

where $b$ is the mean duration of stay.

Under these two assumptions about the distributions of new cases and their duration of stay the simulation programme was run.

\section{Results}

To cater for a model population of 100,000 , the hospital need of 16 beds was made up in fouf different ways -16 arrivals per annum with a mean duration of stay of one year, 8 arrivals per annum staying for two years, 4 arrivals per annum staying for four years, and 2 arrivals per annum staying for, on average, eight years. The results are shown in Table III. In each case the management of 2,000 patients was simulated, first by supplying only the expected need, i.e., 16 beds, then 18 beds, and finally 20 beds.

On supplying only 16 beds, the percentage bed occupancy is about $96 \%$ in all cases while the proportion kept waiting varies from 85 to $90 \%$. As might be expected, the mean waiting time increases with an increased mean length of stay, from one to eight years. Supplying 18 beds gives a percentage bed occupancy of about $89 \%$, with 40 to $50 \%$ of patients having to wait for 0.4 to 3.9 years. With 20 beds the percentage bed occupancy falls to $80 \%$, and the proportion of cases kept waiting also falls to between 25 and $30 \%$, with similar reductions in the mean waiting times.

Since the simulation study began, data were obtained from the D.H.S.S.'s hospital census (Ministry of Health, 1968), which gave a crude analysis of the length of stay of the younger chronic sick (Table IV). It was discovered that no single simple theoretical distribution corresponded to the actual distribution, because while the duration of 
TABLE III

RESULTS OF SIMULATION USING THE NEGATIVE EXPONENTIAL DISTRIBUTION FOR DURATION OF STAY

\begin{tabular}{|c|c|c|c|c|c|c|c|}
\hline \multirow{2}{*}{$\begin{array}{c}\text { Arrival } \\
\text { Rate } \\
\text { (per annum) } \\
\text { (1) }\end{array}$} & \multirow{2}{*}{$\begin{array}{l}\text { Length } \\
\text { of Stay } \\
\text { (years) } \\
\text { (2) }\end{array}$} & \multirow{2}{*}{$\begin{array}{c}\text { Hospital } \\
\text { Need } \\
(1) \times(2)\end{array}$} & \multirow{2}{*}{$\begin{array}{c}\text { Number } \\
\text { of Beds } \\
\text { Available }\end{array}$} & \multirow{2}{*}{$\begin{array}{c}\text { Percentage } \\
\text { kept } \\
\text { waiting }\end{array}$} & \multicolumn{2}{|c|}{ Waiting Time (years) } & \multirow{2}{*}{$\begin{array}{c}\text { Percentage } \\
\text { Bed } \\
\text { Occupancy }\end{array}$} \\
\hline & & & & & Mean & SD & \\
\hline $\begin{array}{r}2 \\
4 \\
8 \\
16\end{array}$ & $\begin{array}{l}8 \cdot 0 \\
4 \cdot 0 \\
2 \cdot 0 \\
1 \cdot 0\end{array}$ & $\begin{array}{l}16 \cdot 0 \\
16 \cdot 0 \\
16 \cdot 0 \\
16 \cdot 0\end{array}$ & $\begin{array}{l}16 \\
16 \\
16 \\
16\end{array}$ & $\begin{array}{l}85 \\
85 \\
85 \\
80\end{array}$ & $\begin{array}{l}8 \cdot 0 \\
3 \cdot 5 \\
2 \cdot 0 \\
1 \cdot 0\end{array}$ & $\begin{array}{l}5 \cdot 0 \\
2 \cdot 2 \\
1 \cdot 3 \\
0 \cdot 7\end{array}$ & $\begin{array}{l}96 \\
96 \\
97 \\
96\end{array}$ \\
\hline $\begin{array}{r}2 \\
4 \\
8 \\
16\end{array}$ & $\begin{array}{l}8 \cdot 0 \\
4 \cdot 0 \\
2 \cdot 0 \\
1 \cdot 0\end{array}$ & $\begin{array}{l}16 \cdot 0 \\
16 \cdot 0 \\
16 \cdot 0 \\
16 \cdot 0\end{array}$ & $\begin{array}{l}18 \\
18 \\
18 \\
18\end{array}$ & $\begin{array}{l}50 \\
50 \\
45 \\
40\end{array}$ & $\begin{array}{l}3.9 \\
1.2 \\
0.6 \\
0.4\end{array}$ & $\begin{array}{l}3 \cdot 3 \\
0 \cdot 8 \\
0 \cdot 5 \\
0 \cdot 3\end{array}$ & $\begin{array}{l}89 \\
90 \\
89 \\
88\end{array}$ \\
\hline $\begin{array}{r}2 \\
4 \\
8 \\
16\end{array}$ & $\begin{array}{l}8 \cdot 0 \\
4 \cdot 0 \\
2 \cdot 0 \\
1 \cdot 0\end{array}$ & $\begin{array}{l}16 \cdot 0 \\
16 \cdot 0 \\
16 \cdot 0 \\
16 \cdot 0\end{array}$ & $\begin{array}{l}20 \\
20 \\
20 \\
20\end{array}$ & $\begin{array}{l}30 \\
30 \\
30 \\
25\end{array}$ & $\begin{array}{l}1 \cdot 0 \\
0 \cdot 9 \\
0 \cdot 4 \\
0 \cdot 2\end{array}$ & $\begin{array}{l}1 \cdot 0 \\
0 \cdot 8 \\
0 \cdot 3 \\
0 \cdot 1\end{array}$ & $\begin{array}{l}80 \\
81 \\
81 \\
80\end{array}$ \\
\hline
\end{tabular}

TABLE IV

MINISTRY OF HEALTH: THE YOUNGER CHRONIC SICK IN HOSPITAL (1967): DURATION OF STAY

\begin{tabular}{|c|c|c|c|c|c|}
\hline \multicolumn{4}{|c|}{ Duration of Stay* } & Number & Percentage \\
\hline $\begin{array}{l}\text { Less than } 1 \text { year** } \\
1 \text { or } 2 \text { years ... } \\
3,4 \text { or } 5 \text { years } \\
\text { More than } 5 \text { years }\end{array}$ & $\begin{array}{l}\ddot{ } \\
\ddot{*} \\
\cdots\end{array}$ & $\begin{array}{l}\ddot{ } \\
\ddot{*} \\
\cdots\end{array}$ & $\begin{array}{l}\ddot{*} \\
\ddot{*} \\
\cdots\end{array}$ & $\begin{array}{r}1,829 \\
725 \\
625 \\
820\end{array}$ & $\begin{array}{l}45 \cdot 7 \\
18 \cdot 1 \\
15 \cdot 6 \\
20 \cdot 5\end{array}$ \\
\hline Total & $\cdots$ & $\cdots$ & $\cdots$ & 3,999 & $100 \cdot 0$ \\
\hline
\end{tabular}

* i.e., Duration of stay from admission to census day. Duration of completed stay will be longer.

** Excluding holiday relief cases.

stay of a high proportion was for less than one year, over $20 \%$ stayed for more than five years. Thus, to simulate more accurately the distribution of the duration of stay, two distributions were combined, one for short-term (five years or less) and one for long-term (more than five years) cases.

The data for short-term cases are very well approximated by a truncated lognormal distribution (a high proportion of patients stay for less than one year). Under this distribution if $\mathrm{P}(t)$ is the probability that a patient's length of stay is $t$ years, then log $P(t)$ follows a normal (or Gaussian) distribution.

As only the total frequency of those staying for more than five years is given in the table, any distribution may be fitted. Assuming that the frequency decreases with time, i.e., more patients stay for six years than for seven years, more stay for seven years than for eight years, and so on, the simplest distribution, i.e., uniformly decreasing with time, was chosen.

The combination of these two distributions is shown in the Figure.

The simulation was repeated using this combined distribution and the results were compared with those using the simple exponential distribution for duration of stay. The results are given in Table V; it can be seen that the exponential distribution with mean duration of stay of four years gives similar (although not identical) results.

Supplying 19 beds per 100,000 population gives an $85 \%$ bed occupancy but keeps about 30 to $35 \%$ of patients waiting for, on average, one year; 17 beds per 100,000 population gives $95 \%$ bed

TABLE V

RESULTS OF SIMULATION USING THE COMBINED DISTRIBUTION FOR DURATION OF STAY

\begin{tabular}{|c|c|c|c|c|c|}
\hline \multirow{2}{*}{$\begin{array}{c}\text { Hospital } \\
\text { Need }\end{array}$} & \multirow{2}{*}{$\begin{array}{c}\text { Number } \\
\text { of Beds } \\
\text { available }\end{array}$} & \multirow{2}{*}{$\begin{array}{c}\text { Percentage } \\
\text { kept } \\
\text { waiting }\end{array}$} & \multicolumn{2}{|c|}{ Waiting Time (yr) } & \multirow{2}{*}{$\begin{array}{c}\text { Percentage } \\
\text { Bed } \\
\text { Occupancy }\end{array}$} \\
\hline & & & Mean & SD & \\
\hline $\begin{array}{l}16 \\
16 \\
16\end{array}$ & $\begin{array}{l}16 \\
18 \\
20\end{array}$ & $\begin{array}{l}80 \\
40 \\
25\end{array}$ & $\begin{array}{l}3 \cdot 0 \\
1 \cdot 5 \\
0 \cdot 6\end{array}$ & $\begin{array}{l}2 \cdot 6 \\
1 \cdot 3 \\
0 \cdot 5\end{array}$ & $\begin{array}{l}98 \\
90 \\
80\end{array}$ \\
\hline $\begin{array}{l}18 \\
18 \\
18 \\
18 \\
18\end{array}$ & $\begin{array}{l}16 \\
18 \\
20 \\
22 \\
24\end{array}$ & $\begin{array}{l}95 \\
75 \\
55 \\
25 \\
10\end{array}$ & $\begin{array}{l}12 \\
4 \cdot 1 \\
2 \cdot 1 \\
0.4 \\
0.3\end{array}$ & $\begin{array}{l}8 \\
3 \cdot 6 \\
1 \cdot 7 \\
0 \cdot 3 \\
0 \cdot 2\end{array}$ & $\begin{array}{l}99 \\
95 \\
90 \\
81 \\
75\end{array}$ \\
\hline
\end{tabular}

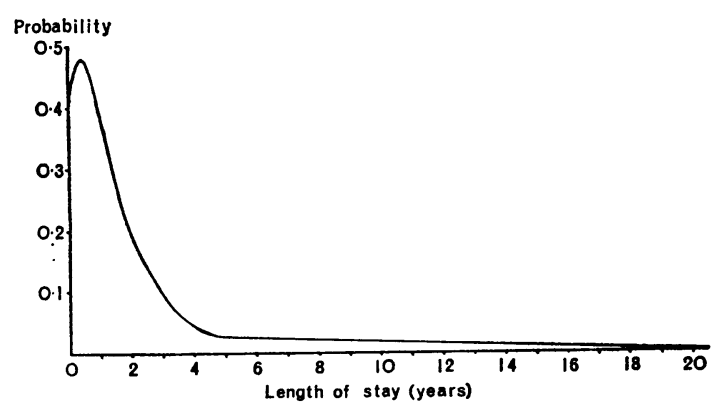

Figure. Theoretical distribution of duration of stay. 
occupancy but increases the proportion kept waiting to about $60 \%$ and their mean waiting time to about two years.

Thesemethods produce estimates of the mean waiting time for all cases. However, in practice, it would be expected that the more urgent (usually short-term) cases would have to wait for only a short period, say less than one month. Assuming that on examination it is possible to estimate crudely the expected duration of stay of a patient, various admission policies could be examined which would allow short-term cases to be admitted almost immediately, while allowing the less serious long-term cases to wait. However, before further work can be carried out on such admission policies, a more detailed breakdown of the duration of stay distribution is required.

Up to now, we have been using the estimate of the hospital need as 16 beds for a population of size 100,000 . But the question arises-by how much are we in error if a more realistic estimate were, say, 18 (which indeed may be the case in a few years' time if our present estimate of 16 is correct)?

Using 18 as an estimate of the hospital need, the simulation was repeated; the results are shown in the lower half of Table V. Instead of 19 beds, providing both a reasonable bed occupancy and mean patient waiting time, 21 beds are now required to satisfy similar conditions.

\section{Holiday Relief}

In the Government Social Survey's National Study of the prevalence of disability in the community, an estimated 42,000 individuals in a population of 48.7 millions were placed in the categories of the most severely disabled (categories 1,2 or 3 ), a rate of approximately 86 per 100,000 . These people, as well as needing help with a commode, chamber, or bedpan practically every night, were handicapped in other ways, such as having to be fed or dressed. We have assumed that the 4,100 in the two most severe categories would accept hospital care, leaving 37,900 in the community-a rate of 78 per 100,000 .

Assuming that those in attendance would accept the offer, we investigated the extra beds that would be required for a 100,000 population in order to relieve them by admitting their charges to hospital for two weeks every year.

Since the prevalence of severe disability in the community is approximately 78 per 100,000 , this involves supplying an extra $78 \times \mathrm{m}_{\mathrm{R} 2}^{2}=3$ bed years per annum.

The simplest way to cater for this is to supply an additional three beds for holiday relief, bringing the total need for the young chronic sick to 19 beds (assuming that 16 beds are originally needed).

However, if most would prefer a summer holiday, the extra 3 bed years must be supplied during the six 'summer' months of April to September. This requires 6 extra beds during the six 'summer' months and none during the six 'winter' months. There seem to be two ways of catering for this need:

(1) The most obvious is simply to supply 6 extra beds for the whole year. This will clearly satisfy the holiday demand but it will also result in a wastage of bed space during the winter months unless the beds can be used by some other unit (such as general medicine or chest diseases) which has a greater need for beds at this time.

(2) If these extra beds cannot be used during the winter months, a better method is to supply only 3 extra beds throughout the whole year and arrange admissions so that 3 bed years are available during the summer months. This would not necessitate 6 beds being available throughout the summer period, as all the distributions of vacant beds shown in Table VI supply the 3 bed years (or 36 bed months). Clearly, it is unlikely that the first distribution will ever arise in practice, as this requires 6 patients to be discharged in March, leaving their beds free for holiday admissions. The other distributions may well occur if ordinary admissions were postponed from

TABLE VI

EXAMPLES OF DISTRIBUTIONS WHICH SUPPLY 36 BED-MONTHS FOR HOLIDAY RELIEF CASES

\begin{tabular}{c|c|c|c|c|c|c}
\hline \multicolumn{9}{c|}{ Number of Beds Vacant for Holiday Relief Patients } & \multicolumn{2}{c}{$\begin{array}{c}\text { Total } \\
\text { Bed-months } \\
\text { Available }\end{array}$} \\
\hline April & May & June & July & August & September & 3 \\
\hline 6 & 6 & 6 & 6 & 6 & 6 & 10 \\
0 & 3 & 6 & 8 & 9 & 9 & 36 \\
2 & 4 & 5 & 8 & 8 & 36 \\
4 & 5 & 7 & 9 & 11 & 36 \\
\hline
\end{tabular}


April (or even earlier) until the end of September when the beds occupied by holiday relief cases would become vacant.

In order to supply the 3 bed years during the six summer months, two holiday policies were suggested:

(1) Postponing all normal admissions that would have occurred between April and September until the beginning of October (or as soon afterwards as beds become available);

(2) Anticipating the holiday demand by postponing all admissions from 1 January onwards until either the holiday demand (starting in April) has been met, or the beginning of October is reached (when all holiday cases are discharged).

Using the combined distribution for the duration of stay of normal cases, both policies were simulated; the results are shown in Table VII. In both cases, even though 6 extra beds are supplied, the bed time available for holiday cases nowhere reaches the required 3 bed years. This is mainly due to the patients who would normally be kept waiting during the winter months being admitted to the 6 extra beds. Thus, supplying extra beds throughout the year has the effect of reducing the waiting time of normal admissions but does not allow the holiday need to be catered for.
To cater for holiday relief cases during the six summer months, 6 extra beds would be required throughout this period, being used for some other purpose during the winter months.

\section{Discussion}

The level of need for beds for the younger chronic sick in Great Britain appears to be in the region of 16 per 100,000 population on average. In order to ensure that every patient obtains a bed at the time he first needs it the level of provision would have to be greater than could be economically justified, and a price of relatively low average bed occupancy has to be paid. If more emphasis were put on the need to run a unit economically (at, say, 95\% average occupancy), the price paid is in terms of longer waiting times for admission. We have seen, for example, that for a population of 100,000 and an average need of 16 beds, providing 19 beds permits a unit to run at an average level of $85 \%$ occupancy, but $30-35 \%$ of cases wait for, on average, one year. If an average bed occupancy of $95 \%$ is required, 17 beds suffice, but $65 \%$ of patients have to wait for, on average, 2.4 years. Thus, a saving of 2 beds and a $10 \%$ increase in efficiency result in doubling both the number of patients kept waiting and their mean

TABLE VII

HOLIDAY RELIEF SUPPLIED UNDER VARIOUS ADMISSION POLICIES

\begin{tabular}{|c|c|c|c|c|c|c|}
\hline $\begin{array}{c}\text { Total } \\
\text { Hospital } \\
\text { Need* }\end{array}$ & $\begin{array}{c}\text { Beds } \\
\text { Supplied }\end{array}$ & $\begin{array}{c}\text { Percentage } \\
\text { kept } \\
\text { waiting }\end{array}$ & $\begin{array}{c}\text { Average } \\
\text { Waiting } \\
\text { Time } \\
\text { (years) }\end{array}$ & $\begin{array}{l}\text { Percentage } \\
\text { Bed } \\
\text { Occupancy }\end{array}$ & $\begin{array}{c}\text { Holiday } \\
\text { Relief } \\
\text { Supplied } \\
\text { (bed-years) }\end{array}$ & Hospital Admission Policy \\
\hline $\begin{array}{l}19 \\
19 \\
19\end{array}$ & $\begin{array}{l}22 \\
24 \\
26\end{array}$ & $\begin{array}{r}20 \\
6 \\
1\end{array}$ & $\begin{array}{l}0 \cdot 8 \\
0 \cdot 3 \\
0 \cdot 2\end{array}$ & $\begin{array}{l}75 \\
68 \\
64\end{array}$ & $\begin{array}{l}0.52 \\
0.55 \\
0.50\end{array}$ & $\begin{array}{l}\text { Normal admissions } \\
\text { delayed from } 1 \text { April to } \\
1 \text { October }\end{array}$ \\
\hline $\begin{array}{l}19 \\
19 \\
19\end{array}$ & $\begin{array}{l}22 \\
24 \\
26\end{array}$ & $\begin{array}{r}20 \\
5 \\
1\end{array}$ & $\begin{array}{l}0.9 \\
0.4 \\
0.4\end{array}$ & $\begin{array}{l}80 \\
70 \\
66\end{array}$ & $\begin{array}{l}1 \cdot 24 \\
1 \cdot 26 \\
1 \cdot 20\end{array}$ & $\begin{array}{l}\text { Normal admissions } \\
\text { delayed from } 1 \text { January } \\
\text { to } 1 \text { October }\end{array}$ \\
\hline
\end{tabular}

*Total hospital need $=$ normal hospital need + holiday relief

(19) $=$ (16) + (3)

TABLE VIII

BEDS REQUIRED TO ACHIEVE 85 OR 95\% BED OCCUPANCY FOR VARIOUS POPULATION SIZES AT A LEVEL OF NEED O̊F 16 BEDS PER 100,000 POPULATION

\begin{tabular}{|c|c|c|c|c|c|c|}
\hline \multirow[b]{2}{*}{$\begin{array}{l}\text { Population } \\
\text { Size }\end{array}$} & \multicolumn{3}{|c|}{$85 \%$ Bed Occupancy } & \multicolumn{3}{|c|}{$95 \%$ Bed Occupancy } \\
\hline & $\begin{array}{c}\text { Beds } \\
\text { Required }\end{array}$ & $\begin{array}{l}\% \text { kept } \\
\text { waiting }\end{array}$ & $\begin{array}{l}\text { Mean Waiting } \\
\text { Time (years) }\end{array}$ & $\begin{array}{c}\text { Beds } \\
\text { Required }\end{array}$ & $\begin{array}{l}\% \text { kept } \\
\text { waiting }\end{array}$ & $\begin{array}{l}\text { Mean Waiting } \\
\text { Time (years) }\end{array}$ \\
\hline 100,000 & 19 & 30 & 0.8 & 17 & 65 & $2 \cdot 4$ \\
\hline 200,000 & 37 & 30 & 0.6 & 33 & 60 & $2 \cdot 2$ \\
\hline 300,000 & 55 & 25 & $0 \cdot 3$ & 48 & 55 & $1 \cdot 9$ \\
\hline 400,000 & 73 & 20 & $0 \cdot 2$ & 64 & 50 & $1 \cdot 3$ \\
\hline 500,000 & 91 & 15 & $0 \cdot 1$ & 80 & 50 & 0.8 \\
\hline
\end{tabular}


waiting time. Clearly, it is important that individuals whose conditions progress relatively rapidly and end, after a period of great dependency, in death should not meet a waiting time which is in excess of the length of their illness. There is an urgent need, therefore, for information about factors associated with variations in survival time after the need for admission has become manifest so that informed decisions can be taken on priorities for admission.

Planning decisions are rarely made for populations of exactly 100,000 , the model population of this simulated exercise. Although for an estimated need of 16 beds per 100,000 population and the achievement of $85 \%$ average occupancy we have seen that 19 beds are required, it does not follow that to achieve $85 \%$ average occupancy for a population of 200,000 exactly 38 (i.e., $2 \times 19$ ) beds would be required (unless they were to be divided between two independent units). In fact, if available at one location, 37 beds would suffice; similarly, only 33 beds, instead of the expected 34, would give $95 \%$ average bed occupancy. The numbers of beds required to achieve either 85 or $95 \%$ average bed occupancy for various sizes of population and a measured need of 16 beds per 100,000 are shown in Table VIII.

In terms of beds required, the table shows that there is little to be gained in supplying large units to cater for the needs of large populations, e.g., to cater for a population of 500,000 (with $85 \%$ bed occupancy) 91 beds are required for a single or several related units, compared with $95(5 \times 19)$ beds if five independent units were used-a saving of only 4 beds in 95 . However, as can be seen in Table VIII, the larger the unit the more efficiently it operates, in terms of both the proportion of patients kept waiting and their mean waiting time. Official advice is for the provision of 50-bed units (Ministry of Health, 1968), which would suffice for a population of $300,000-350,000$ at $95 \%$ bed occupancy, or $250,000-300,000$ at $85 \%$ bed occupancy.

Occasionally, local variations in the amount of chronic sickness in the younger age-groups or in the availability of attendants at home will create differences in absolute levels of need of hospital beds from place to place. In future years, the need may be boosted in most areas by an increasing need to accommodate survivors with disabling congenital abnormalities, such as spina bifida. The size of such a need is difficult to forecast, and it may be wise to ensure that facilities currently being planned are capable of extension if the need arises.

Finally, there is the question of short-term relief. The problem of scheduling admissions for short-term relief within a system providing for those in permanent need of hospital care is very great if economic levels of occupancy and short waiting times are to be achieved. The most satisfactory solution appears to be one in which a separate bank of beds is utilized for the purpose, either throughout the year or by sharing their use with specialties whose demands for beds show wide seasonal variations.

\section{SUMmaRY}

From recent surveys in Great Britain it is calculated that the average level of need of hospital beds for the younger chronic sick is 16 per 100,000 ( 1 bed per 6,250 population).

In order to achieve an average level of bed occupancy of $85 \%$ a unit of 19 beds would be needed for a population of 100,000 . Even then $30-35 \%$ of patients would have to wait, on average, one year for admission. Decrease in the waiting time can be achieved only by lowering the average level of bed occupancy, which means increasing the number of beds per unit of population.

For larger units of population there is a disproportionately smaller increase in the number of beds needed. A 50-bed unit would serve a population of $250,000-300,000$ if the surveyed level of need in the community were for 16 beds per 100,000 , assuming an average level of bed occupancy of $85 \%$. The provision of beds for holiday relief cases is best achieved by setting aside a quota exclusively for that purpose; 6 additional beds per 100,000 population would probably be needed if the demand were concentrated in the summer months, or 3 beds per 100,000 if the demand were spread evenly over the year.

We are grateful to Miss Lynda Jackson for typing and secretarial assistance in compiling this report.

\section{REFERENCES}

BaIley, N. T. J. (1956). Statistics in hospital planning and design. Appl. Statist., 5, 146.

BalintFy, J. L. (1960). A stochastic model for the analysis and prediction of admissions and discharges in hospitals. Proceedings of the Sixth International Meeting of the Institute of Management Sciences, New York. Pergamon, Oxford.

HARRIS, A. I. (1971). Handicapped and Impaired in Great Britain. Office of Population Censuses and Surveys, Social Survey Division. H.M.S.O., London.

MacLennan, W. J. (1972). The young chronic sick at home and in hospital. Hlth. Bull. (Edinb.), 30, 110.

Miller, E. J., and GwYnNe, G. V. (1972). A Life Apart. Tavistock Publications, London. 
Ministry of Health (1968). Care of younger chronic sick patients in hospitals. H.M. Circular (68) 41.

Morris, D., and Handyside, A. J. (1971). Effects of methods of admitting emergencies on use of hospital beds. Brit. J. prev. soc. Med., 25, 1.

Newell, D. J. (1954). Provision of emergency beds in hospitals. Brit J. prev. soc. Med., 8, 77.

NotTingham UNIVERSITY HMC AND NotTINGHAM AND DisTRICT HMC (1971). Report of Working Party of Group Medical Committees on the need for hospital provision for the young chronic sick (Unpublished).
Pearson, N. G., Ashford, J. R., Lowther, C. P., McAlpine, D., Seiler, H. E., ANd Sowden, R. R. (1971). Report on Studies of Disability in Exeter and Edinburgh. Exeter University.

Pike, M. C., Proctor, D. M., and WYllie, J. M. (1963). Analysis of admissions to a casualty ward. Brit $J$. prev. soc. Med., 17, 172.

RANKINE, R., and WeIR, R. M. L. (1967). An Enquiry into the Incidence of Chronic Illness and Disability in the Young and Middle aged. Victoria Hospital, Kirkcaldy.

Young, J. P. (1965). Stabilization of inpatient bed occupancy through control of admissions. Hospitals, 39,41

$$
\text { c }
$$

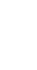

